Izabella Helena GrabowsKa-LePczaK

The Main School of Fire Service in Warsaw, Poland

igrabowska@sgsp.edu.pl

ORCID iD: https://orcid.org/0000-0003-4695-3993

Michae PRZYbYsZ

The Main School of Fire Service in Warsaw, Poland

michalprz@poczta.onet.eu

\title{
THE ROLE OF EDUCATION IN THE FIELD \\ OF SHAPING PUBLIC AWARENESS IN THE EVENT \\ OF TERRORIST THREATS
}

\section{ROLA EDUKACJI W ZAKRESIE KSZTAETOWANIA ŚWIADOMOŚCI SPOŁECZEŃSTWA NA WYPADEK ZAGROŻEŃ TERRORYSTYCZNYCH}

\begin{abstract}
The publication is an assessment and analysis of activities in the field of shaping public awareness in the event of terrorist threats. The aim of the article is to indicate the essence and role of education in the field of terrorist prevention in the modern world. The research was designed to assess the state of knowledge and awareness of the society on terrorist threats. The hypothesis put forward in the research assumed that education is one of the most effective forms of counteracting threats. The study was conducted using a research questionnaire covering two categories of questions: concerning knowledge and checking skills in relation to the logarithms of the procedure and the sources and methods of acquiring knowledge. The results of the research will be a starting point for considering the concept of a comprehensive education system for security in Poland, one of the most important elements of which will be terrorist prevention. The foundation of this concept will be an expert cooperation and the development of effective educational programs.
\end{abstract}




\section{STRESZCZENIE}

Publikacja stanowi ocenę i analizę działań w zakresie kształtowania świadomości społeczeństwa na wypadek zagrożeń terrorystycznych. Celem artykułu jest wskazanie istoty i roli edukacji realizowanej w tym obszarze we współczesnym świecie. W tym celu zaprojektowano badania dotyczące oceny stanu wiedzy i świadomości społeczeństwa na temat edukacji antyterrorystycznej. Hipoteza postawiona w badaniach zakłada, iż edukacja ta jest nie tylko niezbędna, ale jest jedną z najbardziej efektywnych form przeciwdziałania zagrożeniom. Badanie zostało przeprowadzone za pomocą kwestionariusza obejmującego dwie kategorie pytań: dotyczące wiedzy oraz sprawdzenia umiejętności w odniesieniu do logarytmów postępowania. Istotne było także poznanie źródeł i sposobów pozyskiwania wiedzy. Wyniki badań będą stanowiły punkt wyjścia do rozważań nad koncepcją kompleksowego systemu edukacji dla bezpieczeństwa w Polsce, której jednym $\mathrm{z}$ ważniejszych elementów będzie prewencja terrorystyczna. Fundamentem tej koncepcji będzie współpraca ekspercka i wypracowanie efektywnych programów edukacyjnych.

KEYWORDS: education, safety, anti-terrorist education, terrorist prevention.

SŁOWA KLUCzowE: edukacja, bezpieczeństwo, edukacja antyterrorystyczna, prewencja terrorystyczna.

\section{WPROWADZENIE}

Współczesna era terroryzmu została zapoczątkowana wydarzeniami 11 września 2001 r. atakiem na Word Trade Center w Nowym Jorku oraz na budynek Pentagonu w Arlington (Hołyst, 2015, s. 492-493). Zagrożenia terrorystyczne w obecnym świecie mają charakter powszechny i masowy. Dlatego proces podnoszenia świadomości społeczeństwa i przygotowanie do odpowiedniego reagowania na zagrożenie stają się konieczne (Szafrańska, Szafrański, 2014, s. 214-216).

Celem artykułu jest wskazanie istoty i roli edukacji w zakresie prewencji terrorystycznej we współczesnym świecie. Ważne wydaje się wypracowanie kompleksowego systemu prewencyjnego, który będzie wdrażany za pośrednictwem edukacji formalnej, nieformalnej, incydentalnej i autoedukacji. Edukacja formalna stanowi najczęstszą formę przekazywania wiedzy i umiejętności. Jest pojmowana jako system tworzony na podstawie sta- 
łych treści oraz form nauki, zaprojektowany tak, aby objąć proces edukacji od nauczania wczesnoszkolnego aż do poziomu uniwersyteckiego. Dotyczy wszystkich kursów realizowanych przez instytucje oświatowe. Kształcenie nieformalne realizowane jest poza systemem szkolnym. Ma ono na celu zdobywanie wiedzy i umiejętności praktycznych. Różni się od edukacji formalnej głównie metodologią. Edukacja incydentalna jest procesem trwającym całe życie i najczęściej odbywa się nieświadomie, jest niezorganizowana, nieregularna i niesystematyczna. Oznacza nabywanie przez każdego człowieka wiadomości, sprawności, przekonań i postaw na bazie codziennego doświadczenia oraz wpływów wychowawczych otoczenia. W tym przypadku charakter uczenia jest niezamierzony, a można nawet powiedzieć, że przypadkowy. Nie ma sprecyzowanych celów edukacyjnych (por.: Ropski, 2013, s. 185-192; Public awareness and public education for disaster risk reduction: a guides, International Federation of Red Cross and Red Crescent Societies, 2011, s. 21-22). Autoedukacja oznacza umiejętność wpływu na własny rozwój, przejmowanie zadania rozwijania i kształtowania kwalifikacji we własnym zakresie, samokształcenie. Wykorzystanie wszystkich tych elementów w projektowaniu edukacji antyterrorystycznej może okazać się najskuteczniejszym narzędziem przeciwdziałania zagrożeniom (Kozerska, 2005, s. 221-227).

W edukacji formalnej ogromne znaczenie odgrywają nauczyciele szkół podstawowych i ponadpodstawowych zajmujący się tematyką bezpieczeństwa. Treści programowe przedmiotu edukacja dla bezpieczeństwa w szkołach obejmują zagadnienia związane z zagrożeniami terrorystycznymi i dotyczą takich szczegółowych kwestii jak: przyczyny współczesnego terroryzmu, formy aktów terroru, zasady zachowania się podczas ataku terrorystycznego, bezpośrednio po nim (strzelanina, sytuacja zakładnicza, atak bombowy, podejrzana przesyłka) (por. Lesiński, 2019; Breitkopf, 2019, s. 10).

W odniesieniu do pozostałych form edukacji prowadzone są programy i kampanie społeczne dotyczące prewencji antyterrorystycznej. Analiza dostępnych materiałów o tej tematyce wskazuje, że jest ich niewiele. Przytoczyć tutaj należy kampanię 4U!, przygotowaną przez Centrum Prewencji Terrorystycznej Agencji Bezpieczeństwa Wewnętrznego oraz aplikację Mass Event Security Collegium Civitas. 
Centrum Prewencji Terrorystycznej to jednostka Agencji Bezpieczeństwa Wewnętrznego (ABW), która zajmuje się szeroko pojętą profilaktyką antyterrorystyczną. Jej misją jest „kształtowanie kultury bezpieczeństwa poprzez budowanie świadomości antyterrorystycznej w społeczeństwie”. Centrum Prewencji Terrorystycznej ABW realizuje swoje zadania m.in. poprzez: programy szkoleniowe, organizowanie seminariów, warsztatów i kampanii społecznych. Kilka lat temu przygotowana została internetowa kampania społeczna $4 \mathrm{U}$ !. Zawiera ona filmy edukacyjne, animacje wskazujące właściwe zachowanie podczas wystąpienia ataku terrorystycznego. Celem tych działań jest zwiększenie świadomości społeczeństwa w aspekcie zapobiegania i reagowania na zdarzenia o charakterze terrorystycznym. Podczas tych kampanii wykorzystano środki komunikacji społecznej, aby dotrzeć do jak największej grupy odbiorców i docelowo podnieść poziom bezpieczeństwa obywateli, zapoznając ich z opracowaną przez Centrum Prewencji Terrorystycznej ABW procedurą 4 kroków (4U!) - Uważaj, Uciekaj, Ukryj się i Udaremnij Atak. Procedura $4 \mathrm{U}$ ! wskazuje właściwy sposób postępowania w przypadku zagrożenia ze strony masowego zabójcy (ang. active shooter) (Centrum Prewencji Terrorystycznej ABW, 2021).

Jako inny przykład aktywności z zakresu edukacji antyterrorystycznej przytoczyć można aplikację Mass Event Security, opracowaną przez Collegium Civitas oraz City Security, która zawiera algorytmy postępowania w poszczególnych kategoriach zdarzeń (imprezy masowe, acitive shooter, terroryzm bombowy oraz pierwsza pomoc). Aplikacja dostępna jest do użytku na smartfonach lub tabletach. Ideą powstania aplikacji była przede wszystkim konieczność podniesienia świadomości społeczeństwa na temat zagrożeń (City Security Holding. Inżynierowie bezpieczeństwa, 2020).

Jak wskazują autorzy opracowania A strategic framework for terrorism prevention and mitigation in tourism destinations, opublikowanego $\mathrm{w}$ czasopiśmie „Tourism Management”, edukacja antyterrorystyczna powinna być wpisana w międzynarodową strategię zwalczania terroryzmu na całym świecie, odnosić się do środowisk lokalnych i wskazywać na konieczność podjęcia działań systemowych. Zaliczyć do nich trzeba programy edukacyjne, biuletyny informacyjne, ulotki, wydarzenia, organizowanie tzw. dni świadomości (ang. awareness days), podczas których prace edukacyjne będą wyjątkowo 
intensywne. Informacje i aktywności powinny być przeznaczone zarówno dla mieszkańców, jak i turystów (Paraskevas, Arendell, 2007, s. 1560-1573).

Według autorki pracy Terrorism awareness and education as a prevention strategy for first responders grupą społeczną, która powinna być przede wszystkim wyposażona w wiedzę i umiejętności o zagrożeniach terrorystycznych, są służby ratownicze (ang. first responders), w tym ratownicy medyczni i strażacy oraz inspektorzy i technicy pożarnictwa. To grupy, które powinny posiadać wiedzę, która może być wykorzystana w zwiększeniu bezpieczeństwa kraju. Potrzebują one dogłębnego zrozumienia działań związanych z zamierzeniami terrorystów, aby umieć przewidzieć, powstrzymać lub przerwać atak. Autorka na przykładzie Stanów Zjednoczonych odniosła się do skutków nieefektywnego wykorzystania zaangażowania społecznego, braków edukacyjnych i oszczędności na programach uświadamiających i prewencyjnych. Według autorki „ludzie na pierwszej linii” potrzebują zasad i procedur (np. rozpoznanie dziewięciu faz samobójczego zamachu bombowego; kwestie prawne i ochrony osobistej; zasady gromadzenia informacji). Krajowa Strategia Bezpieczeństwa Wewnętrznego oraz Wytyczne Biura Gotowości Krajowej (The National Strategy for Homeland Security and the Office of Domestic Preparedness Guidelines for Prevention and Deterrence) wyraźnie potwierdzają potrzebę aktywnego zaangażowania personelu służb ratowniczych i porządkowych, w tym straży pożarnej, w zapobieganie terroryzmowi. Należy zaakceptować fakt, że najlepszą (i jedyną) metodą pokonania terroryzmu jest edukacja specjalistycznego personelu oraz całego społeczeństwa w zakresie rozpoznawania motywacji poszczególnych terrorystów, metod działania oraz sposobów pozyskiwania funduszy na działalność terrorystyczną. Tylko kompleksowa edukacja wraz z odpowiednim finansowaniem przyczynią się do zapobiegania atakom terrorystycznym w Los Angeles i sąsiednich jurysdykcjach. Ważne są różne zmienne, m.in. implikacje polityczne, podział finansowania, wytypowanie organizacji, agencji, które powinny pracować nad przygotowaniem społeczeństwa na wypadek zagrożeń terrorystycznych (Welch, 2006, s. 39-55; William, Pelfrey, 2007, s. 313-321).

Artykuły Securitising Education to Prevent Terrorism or Losing Direction? Billa Durodie'a oraz Youth, terrorism and education: Britain's Prevent programme Paula Thomasa wskazują na rosnący związek między bezpieczeństwem 
a edukacją, szczególnie w świetle działań brytyjskiego rządu w ramach programu Prevent Duty, który ma na celu przeciwdziałanie radykalizacji, czyli reprezentowaniu coraz bardziej skrajnych poglądów, akceptacji przemocy w celu realizacji swoich zamiarów i manifestowaniu swoich przekonań w różnych środowiskach, w tym na uniwersytetach. Odnoszą się do działań podjętych przez brytyjskiego premiera Davida Camerona, który publicznie ogłosił swoją determinację w walce $z$ tym, co nazywa „plagą radykalizacji”, poprzez wysiłki w szkołach, uczelniach i uniwersytetach. Zamiast sekurytyzacji edukacji, którą przyjmują niektórzy, może to być raczej terapia bezpieczeństwa. W ramach tej terapii powszechnie zaczęto tworzyć programy prewencyjne i edukacyjne, na które przeznaczono setki milionów funtów, aby zachęcić do współpracy i dialogu między władzami a przedstawicielami różnych muzułmańskich grup religijnych i społecznych. Najnowsze strategie antyterrorystyczne, w tym Prevent Duty, wyraźnie odnoszą się do roli odgrywanej przez placówki edukacyjne i instytucje oświatowe (por. Durodie, 2015, s. 21-35; Thomas, 2016, s. 1-15).

Obecna sytuacja Polski na tle innych państw pozostaje dobra, ale nadal istnieje zagrożenie terroryzmem i radykalizmem. W Europie można zauważyć wpływ pandemii na działania terrorystyczne, np. odwoływane są imprezy masowe. Widoczne są działania propagandy terrorystycznej w Internecie. Kryzys ekonomiczny, spowodowany COVID-19, może być traktowany jako powód pogłębiającej się na świecie radykalizacji zarówno postaw, jak i poglądów. Wzrost bezrobocia i biedy w różnych częściach świata może sprzyjać radykalizacji postaw i poglądów i będzie wykorzystywany przez organizacje terrorystyczne. Biorąc to pod uwagę, należy zrozumieć, jak ważne są działania polegające na informowaniu i podnoszeniu stanu świadomości społeczeństwa w zakresie zagrożeń terrorystycznych (Serwis Rzeczypospolitej Polskiej, 2020).

Unia Europejska podejmuje systematyczne działania związane z przeciwdziałaniem radykalizacji i rekrutacji członków przez organizacje terrorystyczne, wskazuje również, że taki obowiązek spoczywa przede wszystkim na państwach członkowskich na szczeblu krajowym, regionalnym i lokalnym. Sposoby przeciwdziałania są bardzo zróżnicowane w poszczególnych państwach członkowskich. Istotne jest dostosowanie polityki społecznej, edukacyjnej i gospodarczej do aktualnych potrzeb i problemów związanych z rosnącym zagrożeniem terrorystycznym (Bossong, 2013, s. 66-79). 
Edukacja antyterrorystyczna powinna być rozpatrywana na dwóch płaszczyznach:

1) poznawczej (poznanie zagrożeń, rozpoznanie odpowiednich symptomów, skutków);

2) praktycznej (kształtowanie odpowiednich postaw w sytuacji zagrożenia).

Współcześnie informacja na temat terroryzmu przekazywana jest głównie przez media, które mimo wszystko działają zgodnie z zamierzeniami terrorystów (przekazywanie dramatycznych wiadomości na wielką skalę). Rzetelna wiedza w tym zakresie powinna dotyczyć: typów zagrożeń terrorystycznych, miejsc ich wystąpienia ze względu na ich specyfikę, prawidłowego postępowania w sytuacji posiadania informacji o potencjalnym zagrożeniu, radykalizacji, werbunku do organizacji terrorystycznych. Część praktyczna szkoleń antyterrorystycznych powinna obejmować umiejętność zachowania się w sytuacji z udziałem zakładników, zachowania się w sytuacji ataku terrorystycznego z użyciem materiałów wybuchowych, środków chemicznych, biologicznych lub radiacyjnych, zachowania się w sytuacji strzelaniny, działania w przypadku otrzymania podejrzanej przesyłki, konieczności ewakuacji w razie zagrożenia terrorystycznego, ewakuacji osób niepełnosprawnych, rannych, udzielania pierwszej pomocy w wypadku obrażeń termicznych, chemicznych oraz zatrucia gazami bojowymi (chemiczno-biologicznymi) (Szafrański, 2017, s. 75-80).

Zgodnie z tymi założeniami zaprojektowane zostały badania polegające na ocenie stanu świadomości społeczeństwa na temat zagrożeń terrorystycznych, których celem jest sprawdzenie zarówno wiedzy, jak i umiejętności (znajomości algorytmów postępowania).

\section{OCENA STANU ŚWIADOMOŚCI SPOEECZEŃSTWA ORAZ WIEDZY NA TEMAT ZAGROŻEŃ TERRORYSTYCZNYCH}

W celu poznania świadomości zagrożeń terrorystycznych w społeczeństwie przeprowadzono badania. Zasadniczym ich celem było zestawienie różnorodnych form współczesnej edukacji - formalnej, nieformalnej, incydental- 
nej - $\mathrm{z}$ aktualnym stanem wiedzy populacji. Postawiona $\mathrm{w}$ badaniach hipoteza zakłada, iż edukacja ta jest nie tylko niezbędna, ale jest jedną z najbardziej efektywnych form przeciwdziałania zagrożeniom. Badania zostały przeprowadzone według następujących kategorii wiekowych: ponżej 18 lat, 18-26 lat, 27-35 lat, 36-45 lat oraz powyżej 55 lat. Próba została dobrana losowo.

Badanie zostało przeprowadzone losowo za pomocą kwestionariusza badawczego, składającego się z metryczki oraz 17 pytań ankietowych. Kwestionariusz zawierał głównie pytania skategoryzowane i kilka pytań otwartych. Projekt badań zakładał pytania sprawdzające wiedzę (bezpieczeństwo, edukacja dla bezpieczeństwa, edukacja antyterrorystyczna), umiejętności postępowania w sytuacji zagrożenia terrorystycznego, znajomość logarytmów postępowania oraz źródła i sposoby pozyskiwania wiedzy.

Ograniczenia badawcze dotyczyły niewielkiej próby badawczej, ze względu na pandemię niemożliwe było bezpośrednie pozyskiwanie danych. Ankieta udostępniona została w Internecie, dlatego też $84,8 \%$ respondentów to osoby w wieku 18-26 lat.

Badanie zostało przeprowadzone w grupie 105 osób, z czego 83,8\% stanowiły kobiety, zaś 16,2\% mężczyźni (rys. 1).

Rysunek 1 .

Udział procentowy w ankiecie kobiet i mężczyzn

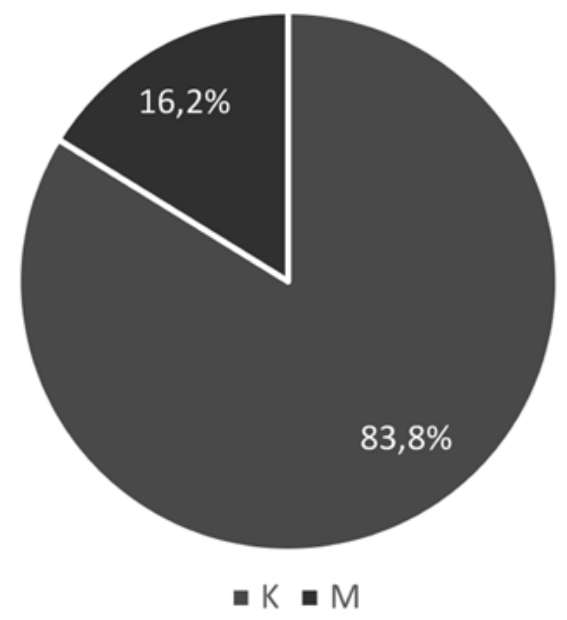

Źródło: opracowanie własne. 
Respondenci zostali podzieleni na grupy wiekowe w przedziałach wiekowych: poniżej 18 lat (2,9\%), 18-26 lat (84,8\%), 27-35 lat (3,8\%), 36-45 lat (5,7\%), 46-55 lat (2,9\%), powyżej 55 lat (rys. 2).

Rysunek 2.

Udział ankietowanych ze względem na wiek

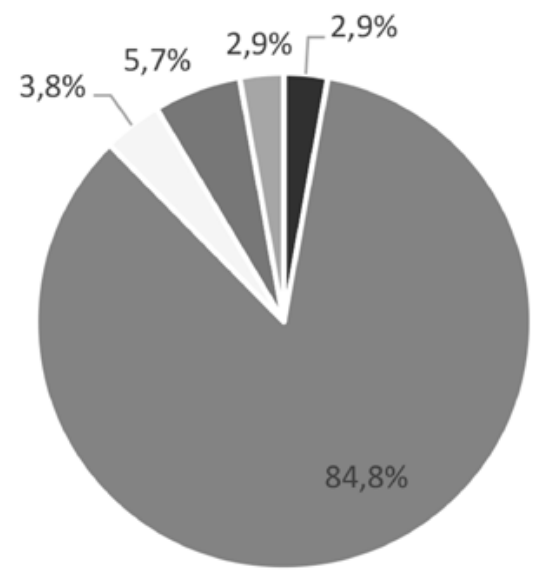

- Poniżej 18 lat | 18-25 $27-35$ | $36-45$ | 46 - 55 | powyżej 55 lat Źródło: opracowanie własne.

\section{PrzedstaWienie WYNIKóW BADAŃ}

Pierwsze pytanie dotyczyło określenia definicji terroryzmu. Respondenci wskazali, iż terroryzm to:

a) zjawisko nagłe i niespodziewane, polegające na użyciu przemocy wobec ludzi w celu zastraszenia ich i uzyskania własnych korzyści;

b) zorganizowane działanie kilku osób o podłożu politycznym lub religijnym;

c) zagrożenie mające charakter asymetryczny polegające na wywarciu wpływu, wymuszeniu określonego zachowania, np. u rządzących;

d) zaplanowane działania polegające na zastraszeniu, o podłożu politycznym lub religijnym;

e) ataki przeciwko niewinnym ludziom na szeroką skalę. 
Kolejne pytanie miało na celu podanie definicji bezpieczeństwa. Respondenci wskazali, iż bezpieczeństwo to:

a) stan komfortu, brak poczucia zagrożenia i strachu;

b) stan psychiczny pozwalający na normalne funkcjonowanie bez obaw o własne życie i życie innych;

c) stan zagwarantowany przez państwo, w którym obywatelom/ludności cywilnej nie zagraża niebezpieczeństwo związane $\mathrm{z}$ wojną czy atakami terrorystycznymi;

d) brak zagrożenia dla siebie i bliskich, pewność, że mogą oni funkcjonować normalnie;

e) uczucie spokoju i wolności.

W następnym pytaniu respondenci zostali poproszeni o wyjaśnienie pojęcia edukacji dla bezpieczeństwa. Wskazano, iż edukacja dla bezpieczeństwa to:

a) kształcenie w dziedzinie bezpieczeństwa;

b) nauka o zagrożeniach i działaniu w sytuacjach zagrażających życiu lub zdrowiu, obrona przed zagrożeniami zewnętrznymi;

c) działanie mające na celu nastawienie odbiorców na konieczność zachowania określonych procedur w przypadku zetknięcia się z niebezpieczeństwem;

d) budowanie świadomości społecznej na temat możliwych zagrożeń w obecnym świecie, zarówno w naszym kraju, jak i poza jego granicami;

e) forma zajęć edukacyjnych, na których dzieciom i młodzieży przekazywane są informacje na temat definicji, zagrożeń i prewencji działań zagrażających życiu i zdrowiu człowieka;

f) edukacja społeczeństwa w zakresie bezpieczeństwa, np. szkolenia z udzielania pierwszej pomocy czy nauka zasad ewakuacji oraz przekazywanie wiedzy o tym, jak należy reagować na sygnały alarmowe.

97\% respondentów uważa, że dzieci powinny być kształcone z zakresu edukacji dla bezpieczeństwa (rys. 3). To pokazuje, że konieczne i potrzebne jest kształtowanie świadomości młodych na temat różnego rodzaju zagrożeń. 
Rysunek 3.

Czy Pani/Pana zdaniem dzieci powinny być kształcone z zakresu edukacji dla bezpieczeństwa?

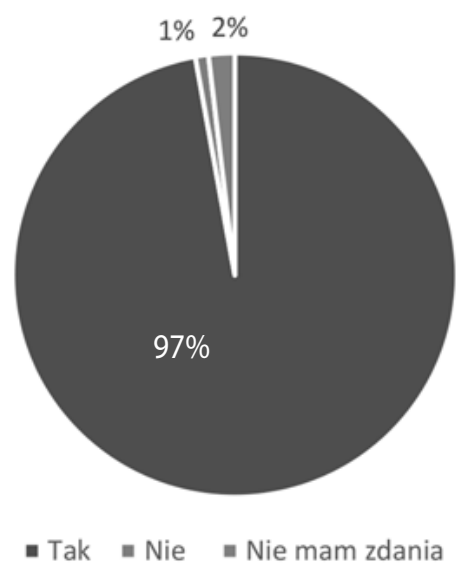

Źródło: opracowanie własne.

W odniesieniu do wieku rozpoczęcia edukacji w zakresie bezpieczeństwa 9,5\% respondentów uważa, że zajęcia powinny być prowadzone od 8 klasy, czyli tak jak obecnie. Natomiast większość jest zdania, że elementy edukacji dla bezpieczeństwa powinny znajdować się w programie nauczania już od klasy 3 (30,5\%) lub od klasy 4 (29,5\%). Rozkład odpowiedzi został przedstawiony na rys. 4.

Rysunek 4.

Od której klasy Pani/Pana zdaniem powinien być prowadzony w szkole przedmiot edukacja dla bezpieczeństwa?

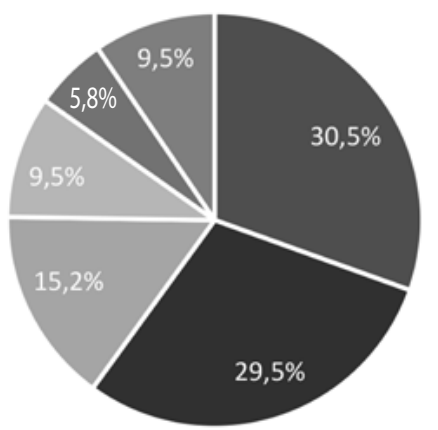

Źródło: opracowanie własne.

- 3 - 4 || 5 | 6 | 7 | 8 (tak jak obecnie) 
Dalsze pytanie miało na celu uporządkowanie przez respondentów w kolejności numerycznej od 1 (mało istotne) do 7 (najistotniejsze) zagadnień, które powinny być poruszane na lekcjach przedmiotu edukacja dla bezpieczeństwa. Do wyboru były takie tematy jak:

- zajęcia praktyczne, np. ewakuacja;

- podstawy pierwszej pomocy;

- zajęcia z przedstawicielami służb (takich jak straż pożarna, ratownictwo medyczne, wojsko itp.);

- metody ochrony przed zagrożeniami;

- przygotowanie do postępowania w przypadku katastrof;

- rozpoznawanie sygnałów alarmowych;

- znajomość zasad ewakuacji.

59\% respondentów na pierwszym miejscu stawia tematykę obejmującą zajęcia praktyczne, np. z próbnej ewakuacji, natomiast na ostatnim miejscu plasują się zajęcia z przedstawicielami służb (jako pierwsze podaje je 30\% badanych osób) (rys. 5).

Rysunek 5.

Proszę o wskazanie, które tematy są najbardziej istotne, a które najmniej

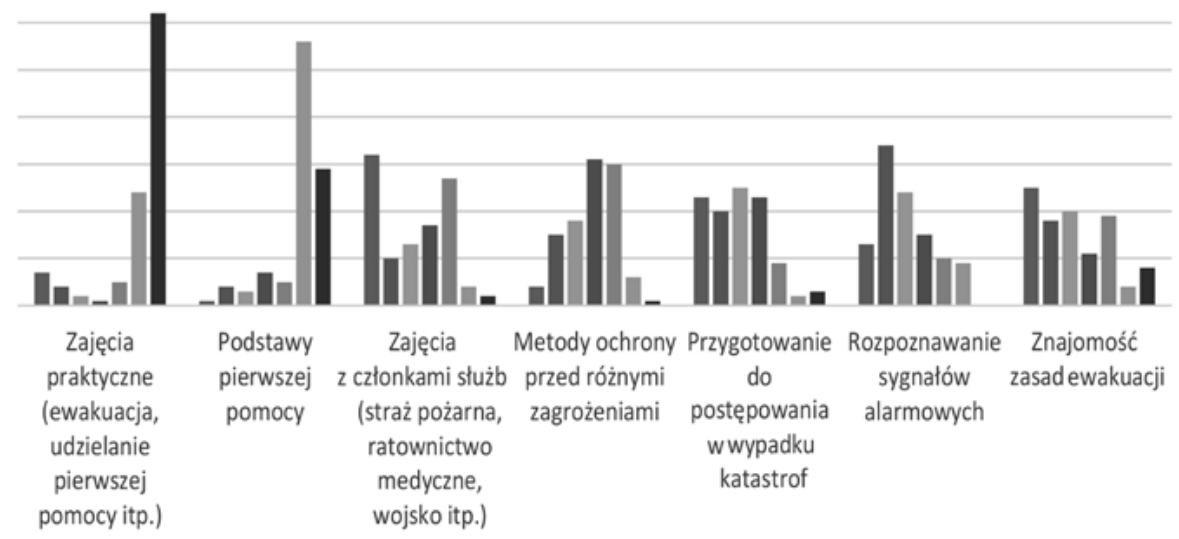

Źródło opracowanie własne. 
Kolejny etap badania dotyczył źródeł pozyskiwania informacji na temat bieżących wydarzeń z kraju i ze świata. Wyniki wskazują, że dla większości osób źródłem informacji jest Internet (103 osoby), następnie telewizja (60 osób), radio (41 osób) i prasa (12 osób), co pokazuje rys. 6.

Rysunek 6.

Źródła informacji na temat bieżących wydarzeń z kraju i ze świata

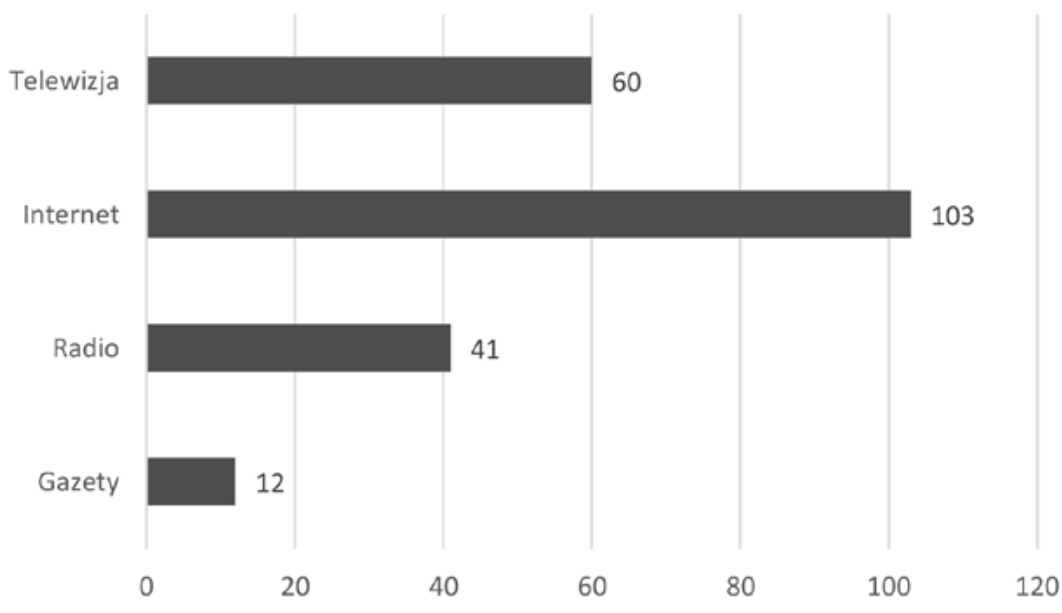

Źródło: opracowanie własne.

Dostępność informacji o sposobach postępowania w sytuacji zagrożenia pozytywnie oceniało $60 \%$ osób (rys. 7). Informacje te mogły mieć następujące formy: ulotek, kampanii reklamowych, komunikatów w metrze czy innych obiektach lub środkach komunikacji oraz mogły pochodzić z innych źródeł. 


\section{Rysunek 7.}

Czy spotkała/spotkał się Pani/Pan z informacjami, jak postępować w sytuacji zagrożenia?

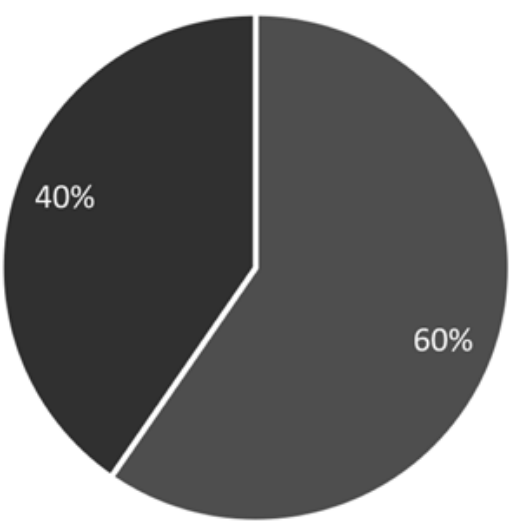

Źródło: opracowanie własne.

- Tak - Nie

$75 \%$ badanych posiada informacje lub zna zasady postępowania w sytuacji zagrożeń (rys. 8).

Rysunek 8.

Czy znane są Pani/Panu zasady postępowania w przypadku zagrożenia?

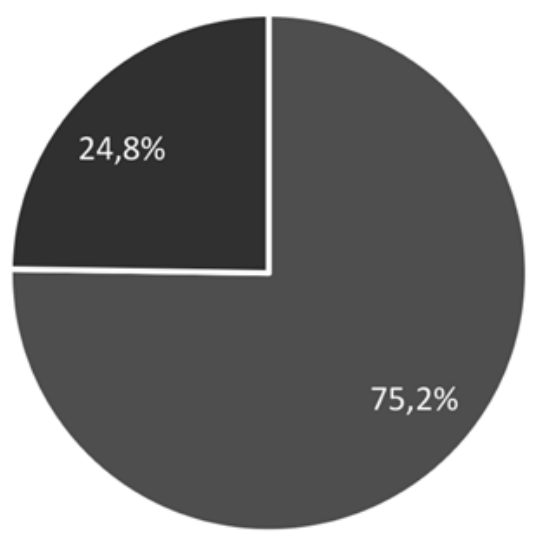

Źródło: opracowanie własne.

- Tak - Nie 
Na kolejnych etapach pytania były uszczegółowione. Z odpowiedzi wynika, że 72,4\% respondentów wiedziałoby, jak należy postąpić w przypadku pozostawionego w miejscu publicznym bagażu (rys. 9). Respondenci wskazali, iż w przypadku zauważenia pozostawionego bagażu:

a) konieczne byłoby zawiadomienie ochrony lub odpowiednich służb;

b) nie wolno dotykać ani otwierać podejrzanego przedmiotu;

c) należy się od niego odsunąć na bezpieczną odległość.

Rysunek 9.

Czy wie Pani/Pan, jak postąpić w przypadku pozostawionego bagażu w miejscu publicznym?

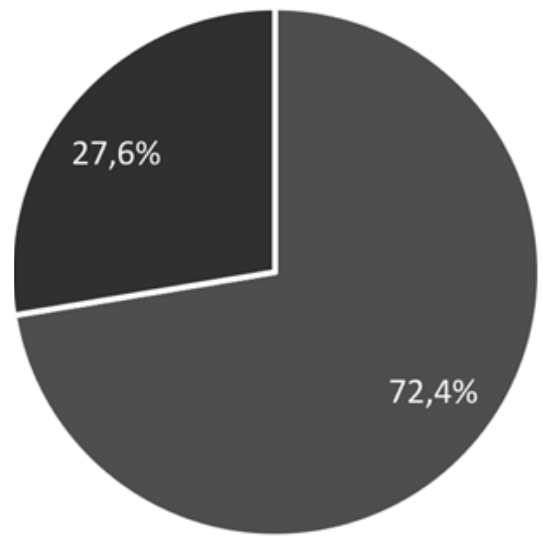

Źródło: opracowanie własne.

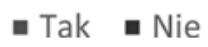

W sytuacji ataku napastnika $\mathrm{z}$ bronią palną 37,1\% osób wiedziałoby, jak należy postąpić (rys. 10). Poszczególne osoby wskazały, iż:

a) należy słuchać poleceń napastnika;

b) nie wolno wykonywać gwałtownych ruchów;

c) w miarę możliwości po rozpoznaniu należy obezwładnić napastnika;

d) należy zastosować metodę „RUN” (Uciekaj), „HIDE” (Ukryj się), „FIGHT” (Walcz) (takiej odpowiedzi udzieliła jedna osoba);

e) należy zachować spokój;

f) należy uciec w bezpieczne miejsce;

g) należy zawiadomić odpowiednie służby. 
Rysunek 10.

Czy wiedziałaby/wiedziałby Pani/Pan, jak się zachować w sytuacji ataku napastnika $\mathrm{z}$ bronią palną?

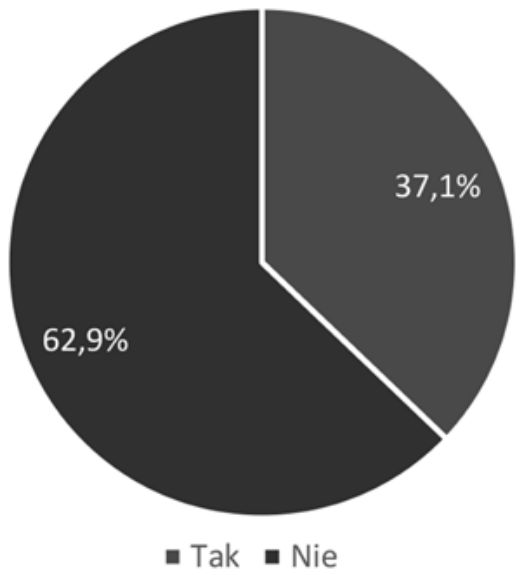

Źródło: opracowanie własne.

Wyniki oceny symptomów świadczących o zbliżającym się zagrożeniu terrorystycznym wśród respondentów wskazują, iż 25,7\% z nich potrafiłoby wskazać oznaki takiego zagrożenia (rys. 11).

Rysunek 11.

Czy potrafiłaby/potrafiłby Pani/Pan rozpoznać symptomy świadczące o zagrożeniu terrorystycznym?

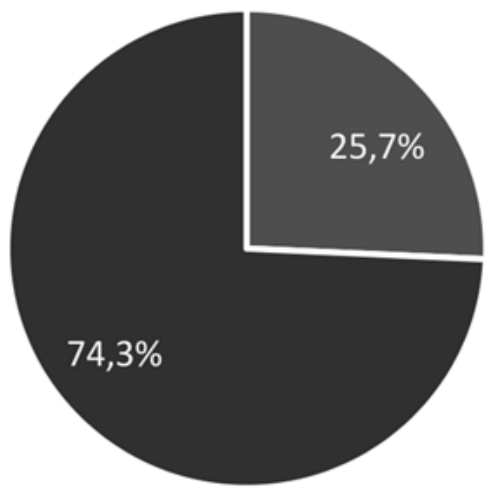

Źródło: opracowanie własne.

- Tak - Nie 
Spektrum takich oznak zostało opisane następująco:

a) robienie zdjęć kamerom monitoringu;

b) podejrzane zachowania, np. nerwowe rozglądanie się dookoła (obserwacja miejsca);

c) nietypowy ubiór, nieadekwatny do pory dnia/roku;

d) pozostawienie w miejscu publicznym podejrzanego bagażu;

e) nienaturalne, chaotyczne gesty;

f) zachowania niepasujące do zachowań pozostałych osób w danym miejscu.

Umiejętności rozpoznania potencjalnego terrorysty wskazało 39\% osób. Wytypowanie cech prawdopodobnego zamachowca przedstawia rys. 12.

Rysunek 12.

Czy wie Pani/Pan, jak można rozpoznać terrorystę?

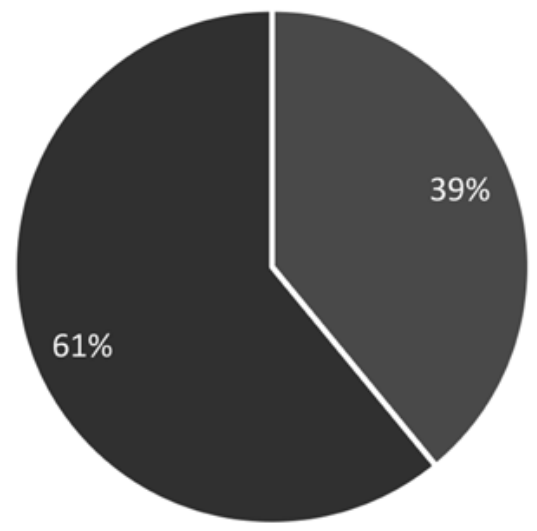

Źródło: opracowanie własne.

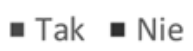

Cechy terrorysty zostały opisane następująco:
a) nienaturalne poszerzeniu w okolicy pasa;
b) ubranie maskujące posturę;
c) zamaskowana twarz;
d) nerwowe zachowanie, rozbiegany wzrok;
e) ukrywaniu się w kącie lub mało widocznym miejscu; 
f) analizowanie sytuacji i obserwacja strategicznych miejsc, takich jak wejścia/wyjścia.

W szkoleniach dotyczących zasad zachowania się podczas ataku terrorystycznego brało udział tylko 12,4\% respondentów (rys. 13). Większość ankietowanych miała zajęcia $\mathrm{z}$ edukacji dla bezpieczeństwa w szkole, jedna z osób odbyła ćwiczenia na wypadek ataku w pracy, inna zaś uczestniczyła w takich zajęciach na studiach (przedmiot poświęcony terroryzmowi), jeden z respondentów brał udział w szkoleniu zabezpieczającym przed Światowymi Dniami Młodzieży w Krakowie, jeden w symulowanym ataku terrorystycznym na stadionie do siatkówki.

Rysunek 13.

Czy kiedykolwiek uczestniczyła/uczestniczył Pani/Pan w szkoleniu dotyczącym zasad zachowania się podczas ataku terrorystycznego?

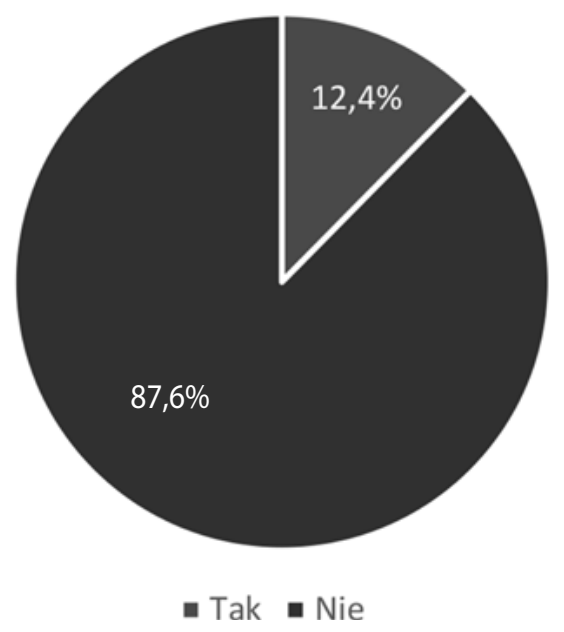

Źródło: opracowanie własne.

Ocena świadomości Polaków na temat zagrożeń terrorystycznych w opinii respondentów wygląda następująco:

a) 56,2\% osób oceniło wiedzę społeczeństwa jako przeciętną;

b) $29,5 \%$ - jako złą;

c) $8,6 \%$ oceniło ją jako bardzo złą; 
d) 3,8\% - jako dobrą;

e) $1,9 \%$ oceniło ją jako bardzo dobrą.

Rozkład odpowiedzi na to pytanie przedstawia rys. 14 .

Rysunek 14.

Jak Pani/Pan ocenia świadomość Polaków na temat zagrożeń terrorystycznych?

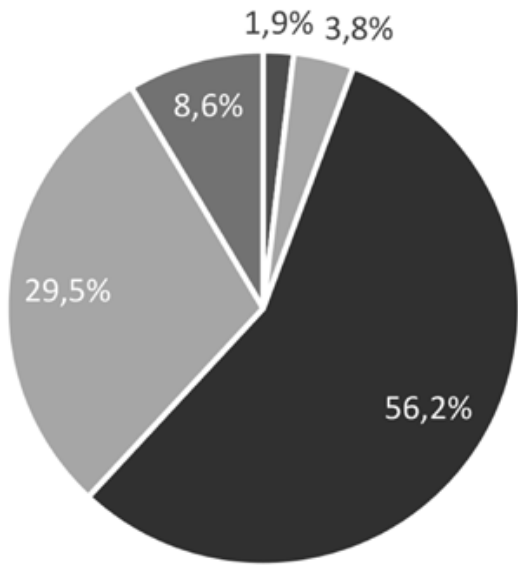

- Bardzo dobrze " Dobrze "Średnio " Źle " Bardzo źle Źródło: opracowanie własne.

Strach przed atakiem terrorystycznym na terenie Polski odczuwa jedynie 16,2\% respondentów - 1,9\% osób udzieliło odpowiedzi „zdecydowanie tak” i 14,3\% - „raczej tak”. 46,7\% nie obawia się takiego zagrożenia (40\% zaznaczyło odpowiedź „zdecydowanie się obawiam” i 6,7\% „raczej się obawiam”), $37,1 \%$ nie ma na ten temat zdania. 


\section{Rysunek 15.}

Czy obawia się Pani/Pan ataku terrorystycznego na terenie Polski?

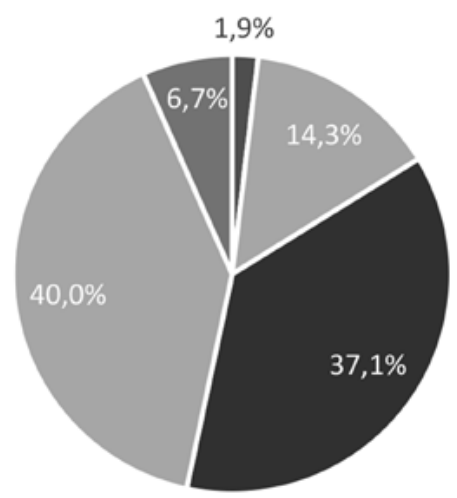

$$
\begin{array}{ll}
\text { - Zdecydowanie tak } & \text { " Raczej tak } \\
\text { = Raczej nie } & \text { - Zdecydowanie nie }
\end{array}
$$

Źródło: opracowanie własne.

Prawdopodobieństwo wystąpienia w przyszłości ataku terrorystycznego na terytorium Polski 11,4\% badanych ocenia jako bardzo duże, natomiast dla $48,6 \%$ jest ono mało prawdopodobne (rys. 16).

Rysunek 16.

Jak ocenia Pani/Pan prawdopodobieństwo wystąpienia w przyszłości ataków terrorystycznych na terenie Polski?

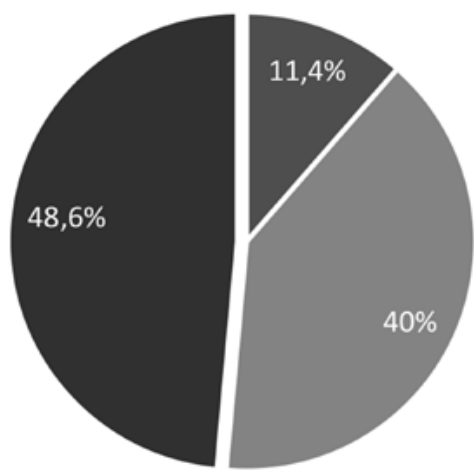

\section{Bardzo prawdopodobne = Prawdopodobne - Mało prawdopodobne}

Źródło: opracowanie własne. 
Jako główną przyczynę terroryzmu badani wskazują:
a) poglądy polityczne;
b) religię;
c) zemstę pojawiającą się w efekcie jakiegoś wydarzenia;
d) różnice etniczne;
e) różnice rasowe;
f) chęć osiągnięcia własnych korzyści.

Formy ataków, które będą najczęściej spotykane w przyszłości to według respondentów:
a) ataki z użyciem broni palnej;
b) ataki z użyciem broni białej;
c) ataki bioterrorystyczne;
d) ataki cyberterrorystyczne;
e) porwania dla okupu;
f) terroryzm bombowy i inne ataki z użyciem środków wybuchowych;
g) porwania samolotu, statków wodnych i innych środków komunikacji.

\section{Podsumowanie}

Analiza uzyskanych wyników pozwoliła sformułować następujące wnioski:

1. Badania pokazały, że większość respondentów zna takie pojęcia jak terroryzm, bezpieczeństwo i edukacja dla bezpieczeństwa. Wiedza ta jest na wysokim poziomie. 97\% respondentów wskazuje na konieczność kształcenia w tym zakresie dzieci i młodzieży.

2. $70 \%$ osób właściwie ocenia swoje umiejętności postępowania w sytuacji zagrożenia. Jednak w przypadku oceny konkretnych umiejętności i konkretnych sytuacji odsetek osób, które znają algorytmy postępowania, jest niewielki (np. na pytanie „Czy wiedziałaby/wiedziałby Pani/Pan, jak się zachować w sytuacji ataku napastnika z bronią palną?” 37\% respondentów odpowiedziało twierdząco).

3. Większość respondentów (60\%) uważa, że elementy edukacji antyterrorystycznej powinny być przekazywane jak najwcześniej. Taka zmiana na 
pewno przyczyniłaby się do wzrostu znajomości zasad bezpieczeństwa i sprawiłaby, iż ludzie częściej właściwie reagowaliby reakcji na zagrożenia. $\mathrm{Na}$ takich zajęciach w opinii ankietowanych powinny znaleźć się zajęcia praktyczne oraz podstawy pierwszej pomocy.

4. Przeprowadzone badania ankietowe pokazały, jak bardzo popularny jest Internet. Większość respondentów (97\%) korzysta z niego jako źródła informacji na temat bieżących zagrożeń. Ma to związek $\mathrm{z}$ wiekiem badanych (84,8\% to osoby w wieku $18-26$ lat).

5. Sytuacja, z jaką większość osób $(72,4 \%)$ umiałaby sobie poradzić, to znalezienie pozostawionego bez opieki bagażu. Taki stan rzeczy prawdopodobnie wynika z popularności tego zjawiska oraz komunikatów nadawanych w środkach transportu. Niewiele osób (37\%) umiałoby poradzić sobie $\mathrm{z}$ innymi zagrożeniami, np. $\mathrm{z}$ atakiem napastnika $\mathrm{z}$ bronią palną, i wyłapać symptomy świadczące o zagrożeniu czy rozpoznać potencjalnego terrorystę. Może to wynikać z ignorancji osób, które uważają, że ta wiedza im się w ogóle nie przyda, ponieważ w przeszłości nie dotknęły ich zdarzenia o charakterze terrorystycznym. Problemem może być też niewystarczający poziom edukacji w szkołach, wynikający z braku kwalifikacji personelu czy zaangażowania uczniów.

Zarówno analiza literatury, dostępnych badań, jak i przedstawione wyniki badań wskazują na konieczność podejmowania działań za zakresu edukacji antyterrorystycznej, która stanowi jedną z najbardziej efektywnych form przeciwdziałania zagrożeniom.

Na świecie od wielu lat tematyka bezpieczeństwa wprowadzana jest coraz wcześniej do procesu wychowania i edukacji społecznej. Jednak warunkiem skuteczności edukacji w zakresie zagrożeń terrorystycznych jest podejście systemowe, czyli takie, które zakładałoby nie tylko jak najwcześniejsze wprowadzenie tych zagadnień do programu nauczania w placówkach oświatowych, ale również zakładałby kontynuację tego typu szkoleń w ciągu całego okresu edukacji oraz objęcie nimi osób dorosłych, znajdujących się już poza procesem edukacji szkolnej (Grabowska-Lepczak, 2017, s. 8).

Podejmowanie działań edukacyjnych jest w pełni uzasadnione i potrzebne. Powinno się to odbywać w sposób systematyczny i systemowy, z wykorzy- 
staniem wszystkich dostępnych form edukacji (Szafrański, 2017, s. 75-80).

Ważnym przykładem może być podjęcie przez Wielką Brytanię bardzo konkretnych kroków w zakresie przygotowania programów informujących i uświadamiających o zagrożeniu terrorystycznym po zamachu bombowym 7 lipca 2005 r. w Londynie (trzy eksplozje w metrze i jedna eksplozja w miejskim autobusie), którego dokonało czterech młodych mężczyzn. Doprowadziło to do szybkiego uruchomienia programu „Prevent” (Department for Communities and Local Government), przygotowanego wcześniej (ale pominiętego) w ramach ogólnej brytyjskiej strategii walki $\mathrm{z}$ terroryzmem CONTEST. Mimo że jest to program edukacyjny prowadzony na szeroką skalę, jest on powszechnie krytykowany, zarzuca mu się stygmatyzowanie społeczności muzułmańskich. Głównym zarzutem jest to, iż „Prevent” zawiera niewiele treści edukacyjnych, a za sprawą swojej teorii radykalizacji postaw nazywany jest edukacją przeciwko ekstremizmowi (Bossong, 2013, s. 67-79).

Program i kampanie społeczne realizowane przez Centrum Prewencji Terrorystycznej ABW zyskują pozytywne opinie właśnie dlatego, że np. kreując postać zamachowca, nigdy nie sugerowano, iż jest to przedstawiciel społeczności muzułmańskiej. W ten sposób uniknięto zarzutów o dyskryminację i stereotypowość myślenia.

Niewątpliwie edukacja społeczeństwa powinna być działaniem kompleksowym, właściwie zaprogramowanym, polegającym na współdziałaniu wielu instytucji rządowych, samorządowych, organizacji pozarządowych (NGO), służb oraz instytucji i placówek oświatowych. Dzięki temu zaprogramowana ścieżka edukacyjna będzie obejmowała wszystkie grupy docelowe (w każdym wieku, z różnych środowisk itp.) oraz będzie wykorzystywała wszystkie formy edukacji (formalnej, nieformalnej, incydentalnej i autoedukacji). Natomiast analiza działań i doświadczenie innych krajów w tym zakresie pozwolą na wyeliminowanie błędnych założeń i obszarów krytycznych. 


\section{Bibliografia}

Bossong, R. (2013). EU cooperation on terrorism prevention and violent radicalization: frustrated ambitions or new forms of EU security governance?, Cambridge Review of International Affairs, Europe University Viadrina, published online: 11 Nov., s. 66-79.

Breitkopf, B. (2019). Program nauczania Edukacja dla bezpieczeństwa, Szkoła ponadpodstawowa, 4-letnie liceum, 5-letnie technikum i branżowa szkoła I stopnia, 1 klasa, Warszawa: Wydawnictwa Szkolne i Pedagogiczne, s. 10.

Durodie, B. (2015). Securitising Education to Prevent Terrorism or Losing Direction?, „British Journal of Educational Studies”, No. 64(1), s. 21-35. DOI: 10.1080/00071005.2015.1107023.

Grabowska-Lepczak, I. (2017). Edukacja dla bezpieczeństwa. Aspekty teoretyczne i praktyczne, Warszawa: Szkoła Główna Służby Pożarniczej, s. 8. ISBN: 9788388446894.

Hołyst, B. (2015). Bezpieczeństwo społeczeństwa, Warszawa: Państwowe Wydawnictwo naukowe, s. 492-493. ISBN: 9788301181277.

Kozerska, A. (2005). Autoedukacja jako jeden z wymiarów edukacji ustawicznej, Częstochowa: Prace naukowe AJD, Pedagogika 14, s. 221-227. ISBN 8370989349.

Lesiński, L.S. (2019). Program nauczania edukacji dla bezpieczeństwa w szkole podstawowej, III etap edukacyjny - zakres podstawowy, opracowany $w$ ramach projektu. Tworzenie programów nauczania oraz scenariuszy lekcji i zajęć wchodzących $w$ skład zestawów narzędzi edukacyjnych wspierających proces kształcenia ogólnego w zakresie kompetencji kluczowych uczniów niezbędnych do poruszania się na rynku pracy, Warszawa: Programu Operacyjny Wiedza Edukacja Rozwój, Wysoka jakość systemu oświaty.

Paraskevas, A., Arendell, B.A. (2007). Strategic framework for terrorism prevention and mitigation in tourism destinations, „Tourism Management”, Vol. 28, Iss. 6, s. 1560-1573. DOI: 10.1016/j.tourman.2007.02.012.

Public awareness and public education for disaster risk reduction: a guides, International Federation of Red Cross and Red Crescent Societies (2011), Geneva, s. 21-22.

Ropski, J. (2013). Dydaktyka szczegółowa edukacji dla bezpieczeństwa, Katowice: Wydawnictwo Akademii wychowania Fizycznego, s. 185-192. ISBN : 9788364036187.

Szafrańska, E., Szafrański, J. (2014). Edukacja na rzecz bezpieczeństwa, „Journal of Modern Science", nr 21(2), s. 211-233. ISSN: 1734-2031. 
Szafrański, J. (2017). Nie jesteśmy bezradni. W: K. Jałoszyński, A. Letkiewicz (red.), Edukacja antyterrorystyczna. Konieczność i obowiązek naszych czasów, Szczytno: Wydawnictwo Wyższej Szkoły Policji, s. 75-80. ISBN: 9788374626156.

Thomas, P. (2016). Youth, terrorism and education: Britain's Prevent programme, „International Journal of Lifelong Education”, International Journal of Lifelong Education, Vol. 35, Iss. 2: Youth, Social Crisis and Learning, s. 1-15. DOI: 10.1080/02601370.2016.1164469.

William, V., Pelfrey, J.R. (2007). Local law enforcement terrorism prevention efforts: A state level case study, Department of Criminal Justice, University of Wisconsin -Milwaukee, Milwaukee, WI 53201, United States, „Journal of Criminal Justice”, No. 35, s. 313-321. DOI: 10.1016/j.jcrimjus.2007.03.007.

Welch, A.L. (2006). Terrorism awareness and education as a prevention strategy for first responders, California: Naval Postgraduate School Monterey, s. 27-36.

\section{Źródła internetowe}

Centrum Prewencji Terrorystycznej, Agencja Bezpieczeństwa Wewnętrznego, www.4u.tpcoe.gov.pl (dostęp: 16.03.2021).

City Security Holding. Inżynierowie bezpieczeństwa, www.citysecurity.pl/technologie/ mass-event-security.htm (dostęp: 16.03.2021).

Żaryn, S. Informacja na temat zwalczania terroryzmu, Serwis Rzeczypospolitej Polskiej, www.gov.pl (dostęp: 16.03.2021). 
